(c) American Dairy Science Association, 2004.

\title{
The Use of Integer Programming to Select Bulls Across Breeding Companies with Volume Price Discounts
}

\author{
M. B. McConnel and D. T. Galligan \\ University of Pennsylvania, School of Veterinary Medicine \\ Center for Animal Health and Productivity \\ 382 West Street Road, Kennett Square, PA 19348
}

\section{ABSTRACT}

Optimization programs are currently used to aid in the selection of bulls to be used in herd breeding programs. While these programs offer a systematic approach to the problem of semen selection, they ignore the impact of volume discounts. Volume discounts are discounts that vary depending on the number of straws purchased. The dynamic nature of volume discounts means that, in order to be adequately accounted for, they must be considered in the optimization routine. Failing to do this creates a missed economic opportunity because the potential benefits of optimally selecting and combining breeding company discount opportunities are not captured.

To address these issues, an integer program was created which used binary decision variables to incorporate the effects of quantity discounts into the optimization program. A consistent set of trait criteria was used to select a group of bulls from 3 sample breeding companies. Three different selection programs were used to select the bulls, 2 traditional methods and the integer method. After the discounts were applied using each method, the integer program resulted in the lowest cost portfolio of bulls. A sensitivity analysis showed that the integer program also resulted in a low cost portfolio when the genetic trait goals were changed to be more or less stringent. In the sample application, a net benefit of the new approach over the traditional approaches was a 12.3 to $20.0 \%$ savings in semen cost.

(Key words: integer programming, semen selection, optimization, dairy cattle)

Abbreviation key: LP = linear program.

\section{INTRODUCTION}

Artificial insemination is an important technology used by the dairy industry. Surveys show that over $80 \%$

Received August 31, 2003

Accepted April 19, 2004.

Corresponding author: M. B. McConnel; e-mail: mmcconne@ wharton.upenn.edu. of dairy herds in the United States use at least some AI today (Plourd, 2000) in contrast to only $70 \%$ of herds in 1992 (Norman and Powell, 1992). Not only is AI being used by more herds, but it is also being used more within each herd. This change is probably due to the widespread adoption of systematic breeding programs where timed insemination is a component (Stevenson, 2001).

Like any important decision, semen selection (which ultimately defines the production levels and characteristics of future cows) must start with concrete goals. Dairy producers must decide which traits are particularly important to them and they must specify target values for each of these traits (Dematawea et al., 1998; Tozer and Stokes, 2002). Once these goals have been defined, a systematic method can be used for efficiently choosing semen.

Many computer programs have been developed to aid in the systematic process of semen selection. Most of these models use simple linear programming as their basis (McGilliard and Clay, 1983a, 1983b; Galligan and Ferguson, 1995; Weigel and Lin, 2000), but others use multi-objective linear programming (Tozer and Stokes, 2001), integer programming (Erba et al., 1991; Nash and Rogers, 1995) or quadratic programming (Schneeberger and Freeman, 1982). The objectives of semen selection models also vary, from minimizing the average cost of semen (Galligan and Ferguson, 1995; Eicker, 1995), while meeting or exceeding target trait values to maximizing the target trait values while remaining within a specified price range (McGilliard and Clay, 1983b). Still other models have been proposed that minimize risk (Schneeberger and Freeman, 1982) or that minimize inbreeding (Weigel and Lin, 2000).

Despite the differences between these selection programs, they share a common characteristic; all of these approaches ignore the impact of volume price discounts. This is not to say that all of these programs ignore price discounts completely. For example, the well-known program developed by McGilliard and Clay (1983a), MAXBULL, allows the user to specify a constant percentage discount across all straws of semen. However, a constant percentage discount is not the same as a volume 
discount. Volume discounts are discounts that vary depending on the number of straws purchased. Thus, there may be no discount if 200 straws are purchased, but a $10 \%$ discount may apply if 300 straws are purchased.

The approach taken by MAXBULL is sufficient if the breeding company offers a constant discount on all straw purchases regardless of quantity. It can also be sufficient if the breeding company offers volume discounts, but the producer plans to purchase semen from only one company. In this case, the producer can estimate how many straws he will need for the year and given that purchase quantity, he can project his volume discount rate and manually input the appropriate discount into the model, thereby creating a constant discount model.

However, when the producer would like to consider the impact of volume discounts on his semen and breeding company choices, an optimization program which incorporates volume discounts (not just a constant discount) is required. If the producer is free to purchase semen from 2 or more breeding companies and at least one of these companies offers volume discounts, it may be optimal to purchase all of the needed semen at one breeding company in order for example, to receive the highest discount level. Or, it may be optimal to split the semen purchase between 3 different breeding companies to receive the first discount level from each company. Thus, when multiple breeding companies are available and these companies offer quantity discounts, it is not adequate to simply indicate a single discount rate for each breeding company. Volume discounts are dynamic since the discount rate changes as the quantity of straws purchased from that breeding company changes. Similarly, the optimal quantity changes as the discount rate changes. This interdependence means that to find an optimal, low-cost portfolio of bulls, the effect of volume discounts must be imbedded in the optimization program.

Recently, breeding companies have used volume discounts as marketing incentives to attract potential customers and to ensure the complete use of their bulls on a given herd. This allows breeding companies to compete for herds rather than for the sale of each straw of semen. Since volume discounts have become such an important part of the semen industry, these discount opportunities should be considered as part of the semen selection decision. Yet, current programs treat volume discounts as afterthoughts, and these types of discounts are only applied if by chance sufficient straws have been purchased from a given breeding company. Under these traditional programs, when a volume discount is received, it is the result of good fortune not of systematic optimization. Traditional methods fail to capture the potential economic benefits of optimally selecting and combining breeding company discount opportunities in the decision process itself.

The purpose of this project was to look at the optimal selection of bulls across multiple breeding companies given unique price/volume discounts. This was accomplished by using integer programming. In the past, integer programming has been used to ensure that the semen optimization program solved for only integer values of straws of semen (Erba et al., 1991; Nash and Rogers, 1995) rather than for fractions of straws. In the current application, integer programming was not used in this manner. Instead, it was used as an on/off switch. Binary integer programming was used to turn different discount rates 'on' when certain minimum quantities were purchased. This allowed the program to model decisions regarding which bulls should be used, from which breeding companies, and at which discount prices. Data from a local Holstein herd of 625 cows was used to demonstrate the application of this methodology and to estimate its benefits over traditional approaches for this herd.

\section{MATERIALS AND METHODS}

\section{The Programming Approach}

A linear programming model $(\mathbf{L P})$ was used to define the objective of minimizing total semen cost subject to a set of trait constraints defined by the producer. These constraints were identified in a manner similar to previously published selection models (Galligan and Ferguson, 1995) with the general format being:

Decision variables:

$$
\text { Bull }_{n, \mathrm{~s}}
$$

Objective Function:

$$
\text { Minimize } \sum_{n=1}^{t} \sum_{s=1}^{3}\left(\text { Bull }_{\mathrm{n}, \mathrm{s}} * \text { Price }_{\mathrm{n}, \mathrm{s}}\right)
$$

Constraints:

$$
\begin{gathered}
\sum_{n=1}^{t} \sum_{s=1}^{3} \text { Bull }_{\mathrm{n}, \mathrm{s}}=\mathrm{N} \\
\text { Bull }_{\mathrm{n}, \mathrm{s}}<15 \% * \mathrm{~N} \\
\sum_{n=1}^{t} \sum_{s=1}^{3} \text { Bull }_{\mathrm{n}, \mathrm{s}} * \text { Trait }_{\mathrm{n}, \mathrm{s}}>,<,=\text { Trait }_{\text {goal }} * \mathrm{~N}
\end{gathered}
$$

where 


$$
\begin{aligned}
\text { Bull }_{\mathrm{n}, \mathrm{s}}= & \text { is the number of straws of bull } \mathrm{n} \text { in breed- } \\
& \text { ing company } \mathrm{s} \text { (for studs } 1,2 \text {, and } 3 \text { ) used } \\
& \text { in the breeding program (rounded to inte- } \\
& \text { ger units), } \\
\text { Price }_{\mathrm{n}, \mathrm{s}}= & \text { is the cost of a straw of semen from bull } \\
& \mathrm{n} \text { in breeding company } \mathrm{s}, \\
\mathrm{N}= & \text { the number of straws required by the } \\
& \text { farm, } \\
\text { Trait }_{\mathrm{n}, \mathrm{s}}= & \text { reported trait value for bull } \mathrm{n} \text { in breeding } \\
& \text { company } \mathrm{s}, \\
\text { Trait }_{\text {goal }}= & \text { trait level goal for the particular dairy } \\
& \text { herd, and } \\
\mathrm{t}= & \text { the number of bulls in each breeding com- } \\
& \text { pany. }
\end{aligned}
$$

The first constraint ensures that the total number of straws of semen required is purchased. The second constraint limits each bull to a maximum of $15 \%$ of the portfolio. This reduces the risk of inbreeding and propagation of unknown deleterious genes (Galligan and Ferguson, 1995). The final constraint ensures that specific trait objectives are met on average by the portfolio of bulls. All of these constraints can be changed to reflect the owners' individual preferences.

Integer programming techniques can be used to augment the general linear program above and to capture the opportunity to identify which combination of breeding companies should be used at which price discount level. Furthermore, integer programming can help the producer to decide whether more straws than are needed should be purchased in order to capture an additional discount tier. For example, a given breeding company may offer a $30 \%$ discount off all straws purchased once a certain volume $\left(\mathrm{Q}_{\mathrm{S}}\right)$ is reached. Under this scenario, producers might find it advantageous to purchase additional semen, which would not be used in the breeding program but would allow for the capture of a volume price discount. A further complication arises when breeding companies offer different volume discounts for different quantities of semen purchased. To capture these types of questions, binary decision variables (integer 1,0 variables) must be integrated into the LP model above.

For example, to select the optimal breeding company to use when one company offers a flat $30 \%$ discount on all straws purchased once a certain volume $\left(\mathrm{Q}_{\mathrm{s}}\right)$ is purchased, the following decision variables and constraints may be added to the general linear programming model:

Additional decision variables are defined:

$$
\frac{\mathrm{X}_{\mathrm{s}}}{\text { Bullexcess }_{\mathrm{n}, \mathrm{s}, \mathrm{d}}}
$$

New Objective Function:

$$
\begin{gathered}
\text { Minimize } \left.\sum_{n=1}^{t} \sum_{s=1}^{3} \sum_{d=1}^{r}{\left(\text { Bull }_{\mathrm{n}, \mathrm{s}, \mathrm{d}}\right.} * \text { Price }_{\mathrm{n}, \mathrm{s}, \mathrm{d}}\right) \\
+\sum_{n=1}^{t} \sum_{s=1}^{3} \sum_{d=1}^{r}\left(\text { Bullexcess }_{\mathrm{n}, \mathrm{s}, \mathrm{d}} * \text { Price }_{\mathrm{n}, \mathrm{s}, \mathrm{d}}\right)
\end{gathered}
$$

Additional constraints:

$$
\begin{gathered}
\left.\sum_{n=1}^{t} \sum_{s=1}^{3} \text { Bull }_{\mathrm{n}, \mathrm{s}, \mathrm{d}}+\text { Bullexcess }_{\mathrm{n}, \mathrm{s}, \mathrm{d}}\right) \\
\geq \mathrm{Q}_{\mathrm{s}} * \mathrm{X}_{\mathrm{s}} \quad \text { for } \mathrm{d}=2 \\
\sum_{n=1}^{t} \sum_{s=1}^{3} \text { Bull }_{\mathrm{n}, \mathrm{s}, \mathrm{d}} \leq \mathrm{M} * \mathrm{X}_{\mathrm{s}} \quad \text { for } \mathrm{d}=2
\end{gathered}
$$

Original constraints:

$$
\begin{gathered}
\sum_{n=1}^{t} \sum_{s=1}^{3} \text { Bull }_{\mathrm{n}, \mathrm{s}}=\mathrm{N} \\
\text { Bull }_{\mathrm{n}, \mathrm{s}}<15 \% * \mathrm{~N} \\
\sum_{n=1}^{t} \sum_{s=1}^{3} \text { Bull }_{\mathrm{n}, \mathrm{s}} * \text { Trait }_{\mathrm{n}, \mathrm{s}}>,<,=\text { Trait }_{\text {goal }} * \mathrm{~N}
\end{gathered}
$$

where

$$
\begin{aligned}
\mathrm{X}_{\mathrm{s}}= & \text { a binary variable that is } 1 \text { if the dis- } \\
& \text { count is used }(\mathrm{d}=1) \text { and } 0 \text { if it is not } \\
& \text { used }(\mathrm{d}=2) . \\
\text { Bull }_{\mathrm{n}, \mathrm{s}, \mathrm{d}}= & \text { the number of straws of bull } \mathrm{n} \text { from } \\
& \text { breeding company } \mathrm{s} \text { purchased at } \\
& \text { price point } \mathrm{d},
\end{aligned}
$$

where

$$
\begin{aligned}
\mathrm{d}= & 1, \text { at the first price point (no discount } \\
& \text { is used), } \\
\mathrm{d}= & 2, \text { at the second price point (the dis- } \\
& \text { count is used), } \\
\mathrm{r}= & \text { the total number of price points } \\
& \text { available at each breeding company, } \\
\mathrm{Q}_{\mathrm{s}}= & \text { the quantity of semen required be- } \\
& \text { fore price point } 2(\mathrm{~d}=2) \text { is available, } \\
\text { Bullexcess }_{\mathrm{n}, \mathrm{s}, \mathrm{d}}= & \text { number of straws of each bull se- } \\
& \text { lected to increase the "volume" to } \\
& \text { achieve a discount. Thus, these } \\
& \text { straws do not contribute to the breed- } \\
& \text { ing target values, but do contribute } \\
& \text { to the total cost of the breeding pro- } \\
& \text { gram, } \\
\mathrm{M}= & \text { the total number of straws needed. }
\end{aligned}
$$


Bullexcess is the number of excess straws that are purchased in order to receive the discount. As such, they contribute to the total price (and thus are added to the objective function), but do not contribute to the trait values (and thus are not added to the original goal trait constraints). Constraining the decision variable, $\mathrm{X}_{\mathrm{s}}$, to be binary forces this variable to be either one (if the discount is used, $d=2$ ) or zero (if the discount is not used, $d=1$ ). If more than $Q_{\mathrm{s}}$ straws are purchased, the $30 \%$ discount is used and the binary variable has the following value: $\mathrm{X}_{\mathrm{s}}=1$.

Equations 1 and 2 are called linking constraints (Ragsdale, 2001). These constraints link Bull ${ }_{n, s, d}$ and $\mathrm{X}_{\mathrm{s}}$, ensuring that the required relationship between these variables is enforced. The first linking constraint (equation 1) sets a minimum order quantity $\left(Q_{\mathrm{s}}\right)$ before price point 2 can be used. It guarantees that when the discount rate from breeding company $\mathrm{s}$ is used (i.e., when $d=2$ and $X_{s}=1$ ), the sum of bulls from that breeding company is greater then the semen quantity $\left(\mathrm{Q}_{\mathrm{s}}\right)$ required for the discount to apply. The second of these constraints (equation 2) uses the variable $\mathrm{M}$ (a number equal to the total number of straws required) to force the total number of discounted semen straws purchased at the discounted price $\left(\Sigma \mathrm{Bull}_{\mathrm{n}, \mathrm{s}, \mathrm{d}=2}\right)$ to equal zero if $X_{\mathrm{s}}$ equals 0 . Together these constraints ensure that the discount is applied to all straws if more than $\mathrm{Q}_{\mathrm{S}}$ straws are purchased and to zero straws if less than $\mathrm{Q}_{\mathrm{S}}$ straws are purchased.

The use of these linking constraints ensures that the decision program considers quantity discounts during the selection decision. Moreover, linking constraints maintain the linearity of the program.

The simple discounting structure above describes a situation in which a certain number of straws are purchased $\left(\mathrm{Q}_{\mathrm{s}}\right)$, resulting in all of the straws receiving a discount. Other purchasing incentives are currently offered in the industry. These involve some form of marginal discounting where, for example, the first 100 straws may be available at full price while the next 200 straws may be available at a $30 \%$ discount. In effect, if 250 straws are purchased, a herd can pay 2 different prices for the same straw of semen. The linking constraints for this problem are shown below and are similar to the previous constraints but are modified to reflect the marginal issues:

$$
\begin{gathered}
\mathrm{X}_{\mathrm{s}}=\text { binary } \\
\sum_{n=1}^{t} \sum_{s=1}^{3}\left(\text { Bull }_{\mathrm{n}, \mathrm{s}, \mathrm{d}}+{\text { Bullexces } \left.\mathrm{s}_{\mathrm{n}, \mathrm{s}, \mathrm{d}}\right)}\right. \\
\geq \mathrm{Q}_{\mathrm{s}} * \mathrm{X}_{\mathrm{s}} \quad \text { for } \mathrm{d}=1
\end{gathered}
$$

$$
\sum_{n=1}^{t} \sum_{s=1}^{3} \text { Bull }_{\mathrm{n}, \mathrm{s}, \mathrm{d}+1} \leq \mathrm{M} * \mathrm{X}_{\mathrm{s}} \quad \text { for } \mathrm{d}=1
$$

where

$$
\begin{aligned}
\text { Bull }_{\mathrm{n}, \mathrm{s}, \mathrm{d}+1}= & \text { the number of straws of bull } \mathrm{n} \text { from breed- } \\
& \text { ing company s purchased at the next mar- } \\
& \text { ginal price point. }
\end{aligned}
$$

The first linking constraint (equation 3 ) ensures that the undiscounted price point $(\mathrm{d}=1)$ is fully utilized before the discounted price point $(d=2)$ is permitted. The last linking constraint (equation 4) links the first price point to the second price point. It forces $\mathrm{X}_{\mathrm{s}}$ to equal one if semen is purchased at the second price point. Together, these 2 linking constraints do not allow any straws of semen at price point 2 to be purchased unless the required number of straws at price point 1 has been purchased. This captures the marginal dimension of the decision problem. In other words, for the discounted price $d=2$ to apply (where $X_{s}=1$ ), the sum of bulls and bullexcess at price point 1 must be greater than or equal to $\mathrm{Q}_{\mathrm{s}}$. The objective function to minimize semen cost will ensure that the higher discounts are applied to the more expensive semen.

\section{Application Data Set}

To demonstrate the application of these principles, a local 625-cow Holstein dairy provided information about the opportunities presented to them from 3 large commercial breeding companies (studs A, B, and C). The trait and semen price data were obtained from the National Association of Animal Breeders May 2003 list of active sires and are summarized in Table 1. Eligible bulls were required to have a minimum reliability index of $95 \%$, resulting in a total of 52 bulls available for selection across the 3 breeding companies. Four traits (average PTA milk, PTA fat, PTA protein, and PTA calving ease) were identified as important to the producer, and the goal values for these traits were stipulated (Table 1).

The producer's objective was to obtain a portfolio of semen that, on average, met or exceeded the trait goals while minimizing cost (LP model). This herd required 1500 straws of semen from proven bulls each year to meet its expected breeding needs.

To understand the value of missed opportunities (due to a failure to consider breeding company selection and volume discounts within the optimization program), 3 selection methods were evaluated. The first method (method 1) reflected a traditional approach, where the LP format presented above was used to select bulls across all 3 breeding companies at their published (non- 
Table 1. Summary of available bulls.

\begin{tabular}{lcccc}
\hline & Goal & Stud A & Stud B & Stud C \\
\hline Number of bulls available & & 23 & 21 & 8 \\
Avg PTA milk (lb) & $>1550$ & 1404 & 1278 & 1133 \\
Max/min PTA milk & & $2343 / 598$ & $2230 / 338$ & $1912 / 591$ \\
Avg PTA fat (lb) & $>45$ & 44 & 37 & 44 \\
Max/min PTA fat & & $76 / 3$ & $75 / 0$ & $74 / 11$ \\
Avg. PTA protein (lb) & $>40$ & 44 & 33 & 39 \\
Max/min PTA protein & & $79 / 10$ & $56 /-4$ & $48 / 26$ \\
Calving ease & & 7.5 & 7.9 & 7.75 \\
Max/min PTA CE & & $10 / 6$ & $13 / 5$ & $10 / 6$ \\
Avg price (\$/straw) & Minimize & 19.57 & 18.71 & 16.88 \\
Max/min PTA price & & $40 / 14$ & $45 / 10$ & $24 / 10$ \\
\hline
\end{tabular}

discounted) prices. If by chance a sufficient quantity of semen was purchased to qualify for a volume discount within a breeding company, then the discount was applied to determine the total discounted semen cost for the herd. Note that the discount was applied after the selection of bulls.

The second method (method 2) used the LP program to select bulls from a single breeding company. This method reflects the fact that producers sometimes choose to use just one breeding company and they often choose the company before selecting individual bulls. The LP format was used to create a separate optimization program for each of the 3 breeding companies. In this case, due to the ability to predict the volume discount (because it was known that 1500 straws would be purchased from one of the 3 companies), the producer could have anticipated the discount level before the bulls were selected or he could have applied the discount after the bulls were selected; both approaches would have led to the same result. In this model, the applicable discounts were applied after the bulls were selected.

The third approach (INTEGER) incorporated the volume discount opportunities into the decision process. The 3 breeding companies offered this farm different volume discounts. Stud A offered a flat $50 \%$ discount on all straws if more than 250 straws were purchased. Thus, if 300 straws were purchased, every single straw received a 50\% discount. Stud B offered a tiered, fixed dollar discount, where a $\$ 6$ discount applied to every straw if more than 500 straws were purchased and a $\$ 7$ discount applied to all straws (even the first 500) if more than 1000 straws were purchased. Stud B also stated that the minimum price a straw could cost was $\$ 5$. Stud C offered a marginal discount where the first 750 straws were full priced, the next 250 straws received a $25 \%$ discount, and any additional straws received an additional $30 \%$ discount.

INTEGER solved for an objective function that minimized the total cost of discounted semen (in contrast to method 1 and 2 which minimized the total cost of nondiscounted semen). To adequately account for these various price discounts, the following integer program was developed:

Decision variables:

$$
\begin{gathered}
\text { Bull }_{\mathrm{n}, \mathrm{s}, \mathrm{d}} \\
\mathrm{X}_{\mathrm{s}, \mathrm{d}} \\
\text { Bullexcess }_{\mathrm{n}, \mathrm{s}, \mathrm{d}}
\end{gathered}
$$

Objective Function:

$$
\begin{gathered}
\text { Minimize } \sum_{n=1}^{t} \sum_{s=1}^{3} \sum_{d=1}^{r}\left(\text { Bull }_{\mathrm{n}, \mathrm{s}, \mathrm{d}} * \text { Price }_{\mathrm{n}, \mathrm{s}, \mathrm{d}}\right) \\
+\sum_{n=1}^{t} \sum_{s=1}^{3} \sum_{d=1}^{r}\left(\text { Bullexcess }_{\mathrm{n}, \mathrm{s}, \mathrm{d}} * \text { Price }_{\mathrm{n}, \mathrm{s}, \mathrm{d}}\right)
\end{gathered}
$$

Constraints:

$$
\begin{gathered}
\sum_{n=1}^{t} \sum_{s=1}^{3} \text { Bull }_{\mathrm{n}, \mathrm{s}}=1500 \\
\text { Bull }_{\mathrm{n}, \mathrm{s}} \leq 15 \% * 1500 \\
\sum_{n=1}^{t} \sum_{s=1}^{3} \text { Bull }_{\mathrm{n}, \mathrm{s}} * \operatorname{Trait}_{\mathrm{n}, \mathrm{s}}>,<,=\text { Trait }_{\text {goal }} * 1500 \\
\mathrm{X}_{\mathrm{s}, \mathrm{d}}=\text { binary }
\end{gathered}
$$

Stud A constraints

$$
\begin{gathered}
\sum_{n=1}^{t}\left(\text { Bull }_{\mathrm{n}, \mathrm{A}, \mathrm{d}}+\text { Bullexcess }_{\mathrm{n}, \mathrm{A}, \mathrm{d}}\right) \\
\geq \mathrm{Q}_{\mathrm{A}} * \mathrm{X}_{\mathrm{A}, \mathrm{d}} \quad \text { for } \mathrm{d}=2 \\
\sum_{n=1}^{t} \text { Bull }_{\mathrm{n}, \mathrm{A}, \mathrm{d}} \leq 1500 * \mathrm{X}_{\mathrm{A}, \mathrm{d}} \quad \text { for } \mathrm{d}=2
\end{gathered}
$$


Table 2. Selection goals and optimization results for three optimization methods.

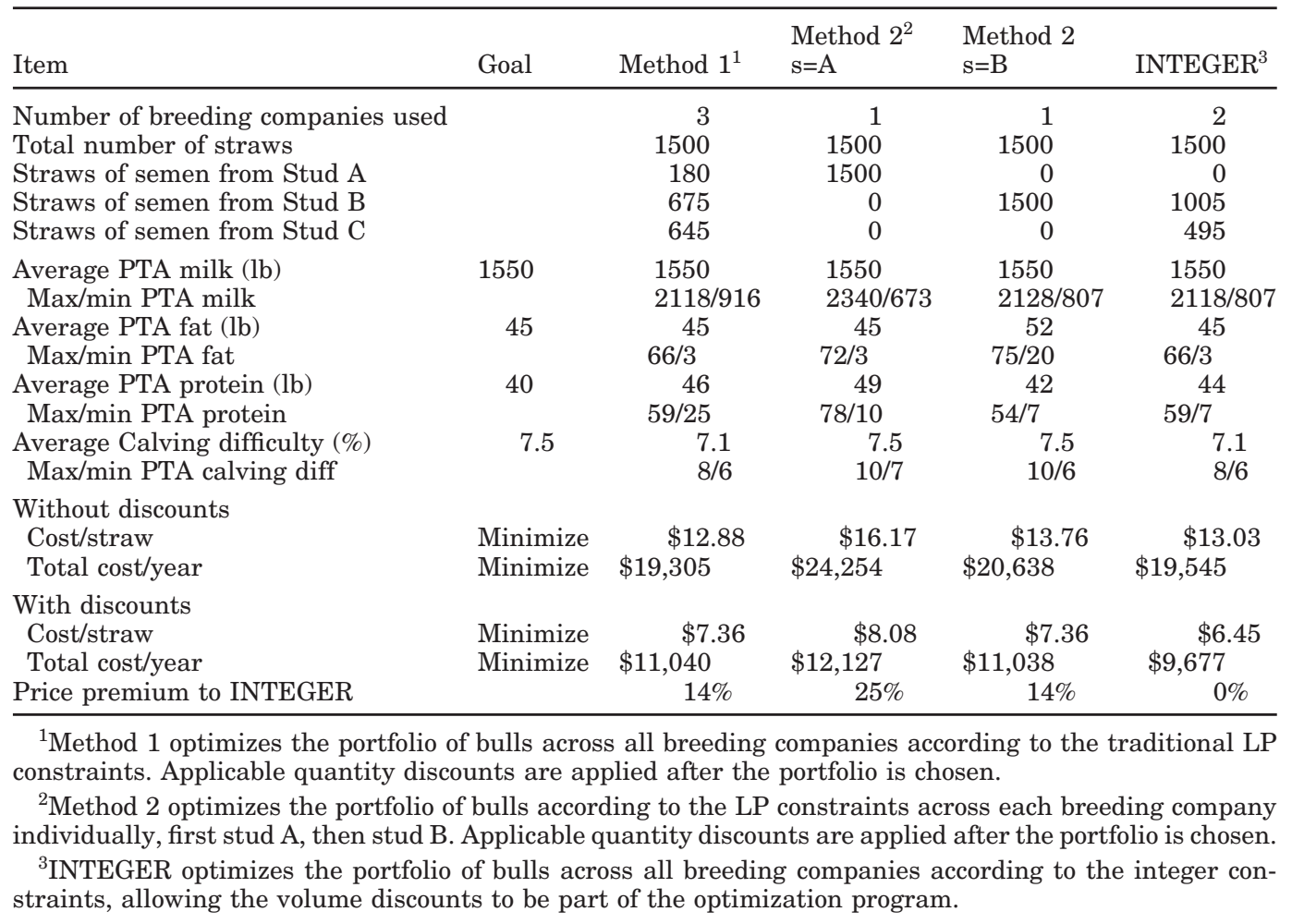

\section{Stud B constraints}

$$
\begin{gathered}
\sum_{n=1}^{t} \sum_{\mathrm{d}=2}^{3}\left(\text { Bull }_{\mathrm{n}, \mathrm{B}, \mathrm{d}}+\text { Bullexcess }_{\mathrm{n}, \mathrm{B}, \mathrm{d}}\right) \\
\geq \mathrm{Q}_{\mathrm{B}, \mathrm{d}} * \mathrm{X}_{\mathrm{B}, \mathrm{d}} \quad \text { for } \mathrm{d}=2,3 \\
\sum_{n=1}^{t} \sum_{\mathrm{d}=2}^{3} \text { Bull }_{\mathrm{n}, \mathrm{B}, \mathrm{d}} \leq 1500 * \mathrm{X}_{\mathrm{B}, \mathrm{d}} \quad \text { for } \mathrm{d}=2,3
\end{gathered}
$$

Stud C constraints

$$
\begin{gathered}
\sum_{n=1}^{t} \sum_{\mathrm{d}=1}^{2}\left(\text { Bull }_{\mathrm{n}, \mathrm{C}, \mathrm{d}}+\text { Bullexcess }_{\mathrm{n}, \mathrm{C}, \mathrm{d}}\right) \\
\geq \mathrm{Q}_{\mathrm{C}, \mathrm{d}} * \mathrm{X}_{\mathrm{C}, \mathrm{d}+1} \quad \text { for } \mathrm{d}=1,2 \\
\sum_{n=1}^{t} \sum_{\mathrm{d}=1}^{2} \text { Bull }_{\mathrm{n}, \mathrm{C}, \mathrm{d}+1} \leq 1500 * \mathrm{X}_{\mathrm{C}, \mathrm{d}+1} \quad \text { for } \mathrm{d}=1,2
\end{gathered}
$$

\section{RESULTS AND DISCUSSION}

The combinations of bulls that met or exceeded the producer's breeding goals, while minimizing the cost of semen were calculated for each of the strategies. Method 1 selected bulls from across all breeding companies, resulting in a low cost portfolio total of $\$ 11,040$ once discounts were appropriately applied, retroactively (Table 2). When the optimization program was constrained to select bulls from within breeding companies (method 2), stud A had a final total semen cost of $\$ 12,127$ and stud B had a final total semen cost of $\$ 11,038$, once discounts were applied. Stud C did not have a combination of bulls that met the producer's breeding goals. This failing was probably due to the fact that only 8 bulls were available for use from stud $\mathrm{C}$ due to the $95 \%$ reliability requirement. This requirement, in conjunction with the previously defined maximum of $15 \%$ of the total semen coming from any one bull, made it impossible for stud $\mathrm{C}$ to provide a feasible solution. Hence, the optimal breeding company selection from method 2 was to use stud B at $\$ 11,038$.

The integer program strategy (INTEGER) incorporated breeding company choice into the optimization routine and resulted in a total discounted semen price of $\$ 9,677$. This represents a $12.3 \%$ decrease in the cost of semen compared with the discounted method 1 portfolio and a $20 \%$ and $12.3 \%$ decrease in the cost of semen compared with the discounted portfolio strategies for just stud A and stud B, respectively. A sensitivity analysis showed that the INTEGER model produced cost savings regardless of whether the producer set higher or lower genetic trait goals (Table 3). The INTEGER program consistently resulted in the low cost solution since it optimized the use of quantity discounts. 
Table 3. Sensitivity of price to changes in trait goals.

\begin{tabular}{|c|c|c|c|c|}
\hline & Method $1^{1}$ & $\begin{array}{l}\text { Method } 2^{2} \\
\mathrm{~s}=\mathrm{A}\end{array}$ & $\begin{array}{l}\text { Method } 2 \\
\mathrm{~s}=\mathrm{B}\end{array}$ & INTEGER $^{3}$ \\
\hline \multicolumn{5}{|l|}{ Low genetic merit ${ }^{4}$} \\
\hline \multicolumn{5}{|l|}{ With discounts } \\
\hline Price/straw & $\$ 7.71$ & $\$ 7.22$ & $\$ 6.02$ & $\$ 5.66$ \\
\hline Total price & $\$ 11,566.00$ & $\$ 10,825.50$ & $\$ 9,036.00$ & $\$ 8,490.00$ \\
\hline Price premium to INTEGER & $27 \%$ & $22 \%$ & $6 \%$ & $0 \%$ \\
\hline \multicolumn{5}{|l|}{ High genetic merit ${ }^{5}$} \\
\hline \multicolumn{5}{|l|}{ With discounts } \\
\hline Price/straw & $\$ 8.83$ & $\$ 9.78$ & $\$ 12.82$ & $\$ 7.96$ \\
\hline Total price & $\$ 13,240.50$ & $\$ 14,665.50$ & $\$ 19,236.00$ & $\$ 11,940.00$ \\
\hline Price premium to INTEGER & $10 \%$ & $19 \%$ & $38 \%$ & $0 \%$ \\
\hline \multicolumn{5}{|c|}{$\begin{array}{l}{ }^{1} \text { Method } 1 \text { optimizes the portfolio of bulls across all breeding companies according to the traditional LP } \\
\text { constraints. Applicable quantity discounts are applied after the portfolio is chosen. }\end{array}$} \\
\hline \multirow{3}{*}{\multicolumn{5}{|c|}{$\begin{array}{l}{ }^{2} \text { Method } 2 \text { optimizes the portfolio of bulls according to the LP constraints across each breeding company } \\
\text { individually, first stud A, then stud B. Applicable quantity discounts are applied after the portfolio is chosen. } \\
{ }^{3} \text { INTEGER optimizes the portfolio of bulls across all breeding companies according to the integer con- } \\
\text { straints, allowing the volume discounts to be part of the optimization program. }\end{array}$}} \\
\hline & & & & \\
\hline & & & & \\
\hline \multicolumn{5}{|c|}{${ }^{4}$ Low genetic merit trait goals include: Average PTA milk $(\mathrm{lb}) \geq 1300$, average PTA fat $(\mathrm{lb}) \geq 35$, average } \\
\hline \multicolumn{5}{|c|}{ PTA protein $(\mathrm{lb}) \geq 30$, average $\mathrm{CE} \leq 7.5$. } \\
\hline \multicolumn{5}{|c|}{${ }^{5}$ High genetic merit trait goals include: average PTA milk $(\mathrm{lbs}) \geq 1800$, average PTA fat $(\mathrm{lb}) \geq 55$, average } \\
\hline
\end{tabular}

The INTEGER program also provided the option of purchasing extra bull semen (Bullexcess ${ }_{\mathrm{n}, \mathrm{s}, \mathrm{d}}$ ), which would not be used in the breeding program, but would allow the producer to reach the quantity threshold for discounts. This semen was assumed to be thrown away and thus, it did not contribute to the breeding goals, but was incorporated into the cost per straw of the semen required by the producer. While Bullexcess was offered as an opportunity, it was not used in this particular application. A sensitivity analysis was performed to identify when Bullexcess might be incorporated into the decision. The INTEGER program was solved again (under the original trait goals) using different values for the total straws of semen required (Table 4).
As was expected, the cost per straw of semen increased when fewer straws of semen were required. This was due to the decreased ability to take advantage of quantity discounts. Furthermore, when fewer straws of semen were required, the option to purchase extra straws that would not be used in the breeding program became more important. This opportunity arises because straws of semen are priced differently; thereby creating an opportunity to purchase inexpensive straws of semen to drive up the volume and achieve a quantity discount, which is applied to the entire semen purchase. Often the first discount is the most substantial, thus it may be economical to purchase excess semen to reach the first discount level.

Table 4. Sensitivity of Bullexcess to changes in number of straws required.

\begin{tabular}{|c|c|c|c|c|c|c|}
\hline $\begin{array}{l}\text { Number of } \\
\text { straws } \\
\text { required }\end{array}$ & $\begin{array}{l}\text { Quantity of } \\
\text { Bullexcess } \\
\text { straws } \\
\text { purchased }\end{array}$ & $\begin{array}{l}\text { Total } \\
\text { number of } \\
\text { straws } \\
\text { purchased }\end{array}$ & $\begin{array}{l}\text { Cost/straw } \\
\text { with } \\
\text { Bullexcess }^{1}\end{array}$ & $\begin{array}{l}\text { Total } \\
\text { cost }\end{array}$ & $\begin{array}{l}\text { Cost/straw } \\
\text { without } \\
\text { Bullexcess }^{2}\end{array}$ & $\begin{array}{l}\text { Total } \\
\text { savings } \\
\text { due to } \\
\text { Bullexcess } \\
\text { purchase }\end{array}$ \\
\hline 1,500 & 0 & 1,500 & $\$ 6.45$ & $\$ 9,675$ & $\$ 6.45$ & $\$ 0$ \\
\hline 1,250 & 0 & 1,250 & 6.64 & 8,300 & 6.64 & 0 \\
\hline 1,000 & 0 & 1,000 & 6.79 & 6,790 & 6.79 & 0 \\
\hline 750 & 0 & 750 & 6.91 & 5,183 & 6.91 & 0 \\
\hline 650 & 100 & 750 & 7.63 & 4,960 & 8.03 & 260 \\
\hline 450 & 0 & 450 & 8.09 & 3,641 & 8.09 & 0 \\
\hline 200 & 50 & 250 & 9.59 & 1,918 & 12.88 & 658 \\
\hline 150 & 100 & 250 & 12.09 & 1,814 & 12.88 & 119 \\
\hline 100 & 0 & 100 & 12.88 & 1,288 & 12.88 & 0 \\
\hline
\end{tabular}

\footnotetext{
${ }^{1}$ Average cost per straw of semen used in the breeding program when Bullexcess is included as a decision variable in the INTEGER LP.

${ }^{2}$ Average cost per straw of semen used in the breeding program when Bullexcess is not included as a decision variable in the INTEGER LP. This portfolio of bulls differs from the portfolio of bulls chosen when Bullexcess is included as a decision variable.
} 


\section{CONCLUSIONS}

Current optimization programs fail to address the decisions that producers face regarding volume price discounts. These discounts can be significant determinants in deciding which bulls to use and from which breeding companies. This application used binary variables to incorporate breeding company selection and quantity discounts into the semen selection program and, it resulted in a more economical portfolio of bulls with a lower total semen cost. In the applied example, a 12 to $20 \%$ savings was observed over traditional optimization methods.

While the problems to be optimized may vary and thus may require different configurations of linking constraints and decision variables, binary programming (which is now readily available on common software; Solver in Excel) can be a powerful tool for making the model more realistic. Incorporating binary variables, instead of ignoring these nuances, will result in better solutions that more closely emulate real life decisions.

\section{REFERENCES}

Dematawewa, M. B., P. J. Berger, and B. E. Melton. 1998. Optimization of sire selection based on maximization of guaranteed income and risk associated with sire merit. J. Dairy Sci. 81:807-816.
Eicker, S. W. 1995. Using linear programming to select a least-cost portfolio of services for dairy herds. American Dairy Science Association, 78. (Abstr.)

Erba, E. M., J. G. Fadel, and T. R. Famula. 1991. The use of integer programming in dairy sire selection. J. Dairy Sci. 74:3552-3560.

Galligan, D. T., and J. D. Ferguson. 1995. Application of linear programming in bull selection for a dairy herd. JAVMA 206:173-176.

McGilliard, M. L., and J. S. Clay. 1983a. Breeding programs of dairymen selecting Holstein sires by computer. J. Dairy Sci. 66:654659.

McGilliard, M. L., and J. S. Clay. 1983b. Selecting groups of sires by computer to maximize herd breeding goals. J. Dairy Sci. 66:647-653.

Nash, D. L., and G. W. Rogers. 1995. Herd sire portfolio selection: A comparison of rounded linear and integer programming. J. Dairy Sci. 78:2486-2495.

Norman, H. D., and R. L. Powell. 1992. Genetic Change Attained and Possible. Pages 59-66 in Large Dairy Herd Management. American Dairy Science Association, Savoy, IL.

Plourd, R. 2000. The drive for efficiency. Dairy Herd Management. Online. Available: http://www.dairyherd.com.

Ragsdale, C. T. 2001. Spreadsheet Modeling and Decision Analysis, $3 \mathrm{E}$. South-Western College Publishing, Cincinnati, OH.

Schneeberger, M., and A. E. Freeman. 1982. Application of portfolio theory to dairy sire selection. J Dairy Sci. 65:404-409.

Stevenson, J. S. 2001. Reproductive management of dairy cows in high producing herds. J. Dairy Sci. 84(E. Suppl.):E124-E143.

Tozer, P. R., and J. R. Stokes. 2001. Using multiple objective programming in a dairy cow breeding program. J. Dairy Sci. 84:2782-2788.

Tozer, P. R., and J. R. Stokes. 2002. Producer breeding objectives and optimal sire selection. J. Dairy Sci. 85:3518-3525.

Weigel, K. A., and S. W. Lin. 2000. Use of computerized mate selection programs to control inbreeding of Holstein and Jersey cattle in the next generation. J. Dairy Sci. 88:822-828. 